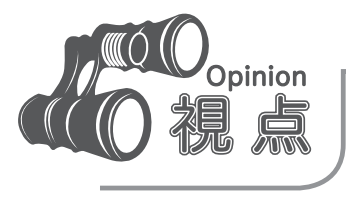

\title{
フランス高等教育機関の図書館 事情
}

\section{1 ）グランゼコール付属図書館}

\section{パリ日本文化会館図書館首席司書 杉田千里}

\section{1.はじめに}

「学歴社会」「一流大学」「受験戦争」という言葉 に象徵されるように，日本でも社会における学歴を 重要視する傾向があるが，フランスでは，日本以上 に出身校重視の「超学歴主義」が非常に強い国であ るように思う。フランスの高等教育機関は，大きく 分けて, 通常の大学とグランゼコールとの2つの組 織に分類することができる。相互間の交流，つなが りはあるものの，フランス学歴社会の中では，この 2つの組織の教育水準，また社会的位置づけはまっ たく違い, 学生は, 卒業後の社会的地位の格差を目 の当たりにすることになる。

\section{2. グランゼコールの特色}

Grandes Écoles（グランゼコール）とは，革命後の 帝政を支える将官や国内再建のための工事の指導を 行うエリート技術者育成の目的で18世紀初めに設 立された。その後今日に至るまで，グランゼコール の卒業生は，さまざまな分野で影響を与える立場に ついていることが多く, 特に, 政財界では, グラン ゼコール卒業生が多数活躍しているのが見られる。 グランゼコールには, 国立の社会科学, 人文科学分 野の機関と, 私立や商工会議所が経営する工学, 経 営学などの分野を力バーする機関とがある。これら は，フランス国中に分散しているものの，名高いグ ランゼコールは, 首都パリや主要大都市に集中して
いる。

グランゼコールの学生になるためには, バカロレ ア (大学入学資格試験) 取得後, 高校付属のグラン ゼコール準備校（2年制）へ入学するための書類選 考に通らなければならない。そして, 準備校を終え るとグランゼコール入学選抜試験がある。準備校の 学生であっても, 自動的にグランゼコールの入学が 認められているわけではないのである。

グランゼコール入学者の大半は, 高学歴の両親を 持ち, 良好な家庭環境で育った特定階級の子女であ り，社会階級をより固定化するものとして，グラン ゼコールそのものが批判されている。そのため, 数 年前から幾つかの機関で自主的に準備校以外の学生 を対象に特別枠を設け，広く学生を募集するところ も出てきているが，大きな改革までには至っていな い。しかしながら，グランゼコールは，このような 厳しい選抜試験を通り抜けてきた学生が入学してい るのであり, 教師陣や職員をはじめ, 建物や併設さ れている施設などに至っても大学以上に惠まれた環 境が整備されている。

\section{3. グランゼコールにおける図書館運営}

本稿では，著者が勤務したENSCP注1)（フランス国 立パリ高等化学学校) を例に学校内組織図と図書館 の位置, 運営について紹介する。

国立大学同様, 国立グランゼコールにおいても, 学内に教育省とCNRS注2) (国立科学研究セン夕ー) 
という2つの組織が併存した形になつており, 職員 および研究者もこの2組織のどちらかに所属してい る。職員の振り分けは, 一般事務職, 教職員 (教授, 准教授）の一部が教育省所属職員。教職員（教授, 准教授）の一部，研究者（研究のみで授業を持たな (), 研究所助手, 研究所事務員がCNRS所属職員と なっている。ちなみに図書館長はCNRSに属するが, 補助員は教育省に属する職員であった。

組織図上は，図書館は学長に直結した形になって いるが, 運営面では, 図書館長, 学長以下, 数人の 教授 (学内CNRS研究所所長を含吉) 也研究者 (CNRS 研究所）による図書館運営委員会によって, 予算, 資料購入・購読を含めた運営方針が決められる。そ のため, 図書館は学内研究者（研究所）の影響を強 く受けた形となっており, 図書館サービスにおいて も，在学生よりも研究者, 研究所の依頼に優先的に 応える傾向にある。また，各研究所にはそれぞれ規 模に差はあるものの, 図書室またはドキュメントセ ンターを併設しており，そのコレクションとの兼ね 合いも含め, 図書館長は, それぞれの研究所所蔵コ レクションを把握し，必要な際には，内部協力を依 頼できるような関係を築いておく必要がある。

\section{4. 図書館資料とサービス}

総合大学図書館と違い，所蔵資料には一般的資料 （日刊紙，辞書，百科事典など）はなく，專門分野 の資料のみで構築されている。グランゼコールの多 くは，設立から長い歴史があるため，その資料も歴 史のあるものが多い。ENSCPも例外ではなく, 1906 年にフランス人として最初にノーベル化学賞を受賞 したモワサン注3) が，ENSCPの前身である応用化学 院の学長であったこともあり, 図書館には19世紀後 半からの化学関係資料が所蔵されている。

グランゼコール付属図書館の特徵として, 専門 分野の雑誌, 定期刊行物のタイトル数の豊富さが 上げられる。電子ジャーナル，オンライン・デー
タベースアクセスにおいても同様で, 例えば無機 化合物データベース「Gmelin」は，著者が勤務した 1999年にはフランス国内で2機関のみしかアクセス 権を持っていなかったため, フランス遠方から調査 依頼などの問い合わせが多く寄せられた。このよう な優遇された状況も,グランゼコールという組織と CNRS研究所の図書館への協力が効果的に機能して いる証であると思う。先に述べたように，CNRSは 研究が目的の組織であり, そのための予算がつくの だが, 教授をはじめ研究者は, それぞれ研究所の助 手, 博士課程の学生と研究活動や, 必要に応じて文 献調査を行う。しかしながら, 研究者は時間の制約 があるため, 博士課程の学生に文献調査を指導する 時間を十分に持てない。また研究者の中には, デー 夕ベース検索に不慣れなため補助が必要な者もい る。このような問題に対応するため, それぞれ研究 所が各々の研究費で必要なデータベースのアクセス 権を取得し, 学内図書館にデータベースアクセス権 が貸与される。その代わりとして, 研究者がデータ ベース検索をする際に, 図書館の職員が研究者に対 して優先的に指導, 協力を行うよう便宜を図るとい う合意がなされている。これにより，フランスでは 稀なデータベースアクセスを含めた資料が学校図 書館にあるのである。その一方, 研究所購入の電子 ジャーナルやデータベースへのアクセスは, 出資研 究所からの使用制限のため, 限られたものになって おり，研究者限定使用のものもある。

ちなみに, 私立の経営学分野の学校では, 在学生 すべてが，無料で，企業や産業界などのビジネス情 報や時事関連データベースへのアクセスを認めてお り, 一部の機関では, 学生のアカウントを通して, 自宅からでもアクセスできるよう整備しているとこ ろもある。

紙媒体資料の一部は, スペースの問題から閉架書 庫にあるものの, そのほかのものは, ほぼすべてを 開架式にしてあるので, 在学生が自由に手に取るこ とができる。 
国内外相互貸借, 文献複写サービスは, 一般的に 在学生は, 送料, 文献複写代は上限内であれば無料 もしくは一部負担であるが, 研究者, 博士課程の学 生などは, 上限なしで各所属研究所が全額負担す る。このサービスにかかる費用は，図書館が一括支 払いするので, 規模や利用度によって, 各研究所が 先に一定金額を図書館に供託するケースと, サービ スが発生するごとに図書館から研究所へ料金を請求 するケースとがある。

このほかに，ENSCP図書館には，特色のあるサー ビスとして, 産業界, 企業情報資料の提供がある。 これもグランゼコールという, 歴史があり, 専門業 界にこれまで多くの卒業生を送り出してきた実績 と, その卒業生たちの会による後輩, 学校への協力 や援助を惜しまない姿勢によって成り立っている。 フランスの高等教育機関では, 学士号, 修士号を取 得するために, 在学中に学外組織で研修を受ける期 間が組み込まれており, 学内での授業と学外での研 修との総合評価により, 学位が授与される。このた め, 学生は, 入学後授業を受け, 個々の研究を進め ながら，研修の受け入れ先を検討しなければならな い。日本の大学では, 就職相談室という就職に関わ る資料や，企業情報を閲覧できるスペースがあった ことを覚えているが, まさにその企業, 業界関連資 料の部分が図書館の中にあると思っていただきた い。企業からの研修斡旋, 相談などは, 学生課にあ たる部署が一括しているが，資料に関わるものは， 図書館で保管している。それらの資料の収集は，卒 業生の会を経由して送られてきたもの, 企業から学 長，教授宛に送られてきたもの，企業を訪問した学 生課の職員から移管された資料のほかに，図書館で 雑誌・新聞の関係記事をまとめ, 分類したファイル がある。在学学生数が, 大学に比べはるかに少ない こともあるが，一般的にグランゼコールの学生は， 研修先や就職先を探すのにそれほどの困難はなく， 企業や研究機関からの募集の件数が，在学生数を超
えることが多いという状況の中, 学生は, これらの 資料を企業選択のために利用している。

余談になるが，筆者が赴任した際，ENSCP図書館 では, 図書館システムと図書館内設備の老朽化のた め, 全面的な改装工事を必要とする状態であった。 そこで, ENSCPの学長が, 某化学薬品会社に図書館 の改装計画を打診し，その会社の現取締役がENSCP 卒業生であることから, 全工事費をその企業に負担 してもらうということがあった。まさに学校と企業 (卒業生) の信頼関係がいかに密接であるかがわか る出来事だと思う。フランスの国立大学では企業と の密接な関係がなく, 予算管理の複雑なことなどか ら，こういったことはまず起こりえない。

専門教育を受けた学生が即社会で活躍できるよう 環境の整備を行うグランゼコールと, 企業との信頼 関係が，これまでの長い歴史の中で築かれてきたの である。こうして各業界で活躍しているグランゼ コールの卒業生は，信頼できるエリート校の卒業生 を採用するという，排他的な機構が作られるのであ る。

最近では，時代の変化とともに，このような閉鎖 的エリート優先社会を非難する声が高まってきてお り, 旧弊な社会構造も徐々に変わっていくのではな いかと思う。しかしながら, 環境を整備し, 広い社 会階層から有能な人が集まるような教育機関を準備 しなければ, 結局一部に人材が集中してしまうこと は避けられないように思う。

\section{執筆者略歴}

杉田 千里（すぎた ちさと）

1993年京都外国語大学卒業。1996年から1998年まで ENSSIB（フランス国立情報科学図書館高等学院）に在学 し, 情報科学・司書職上級課程, 文献情報科学におけ る高等専門研究課程を修了。ENSCP (フランス国立パリ 高等化学学校) 図書館長, アジア交流推進研究所ドキュ メントセンター長を経て，2006年よりパリ日本文化会 館図書館首席司書。 


\section{本文の注}

注1) École nationale supérieure de chimie de Paris

注2) Centre national de la recherche scientifique

注3) Henri Moissan (1852-1907)

\section{参考資料}

a) 柏倉康夫. エリートのつくり方一グランド・ゼコールの社会学. 筑摩書房, 1996, 204p. 